\title{
Opportunities for Chemical Manufacturing Using Natural Gas Feedstocks in the San Juan
}

Basin

Supporting Information

Sean E. DeRosa, ${ }^{1 *}$ P. Sue Downes, ${ }^{2}$ Rick Lentz, ${ }^{2}$ and David T. Allen ${ }^{1}$

${ }^{1}$ Center for Energy and Environmental Resources, University of Texas at Austin, 10100 Burnet Road, Bldg. 133, R7100, Austin, TX 78758, United States

${ }^{2}$ PRISM Analytics Corporation, 1155 University Blvd SE, Albuquerque, New Mexico 87106, United States

*Author to whom correspondence should be addressed (E-mail: sean.derosa@utexas.edu)

\section{Table of Contents}

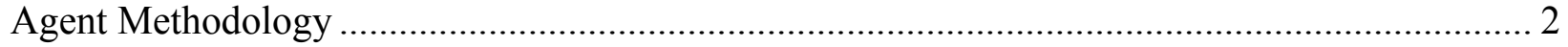

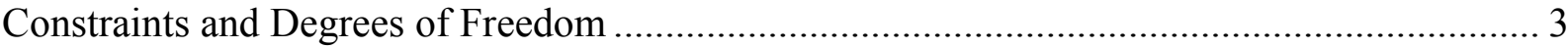



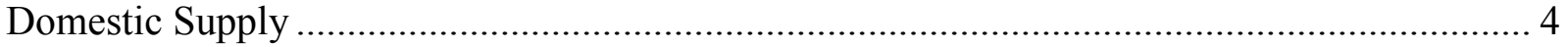

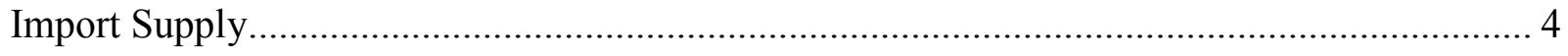

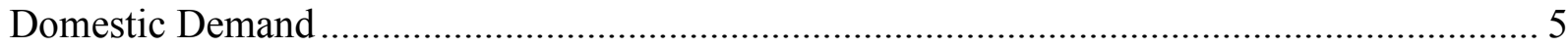

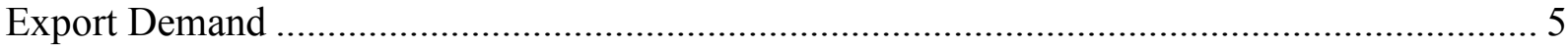

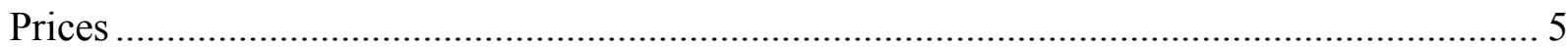

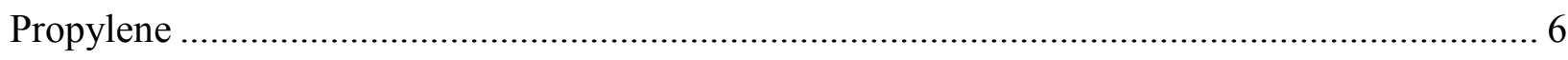

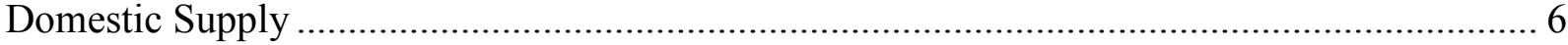

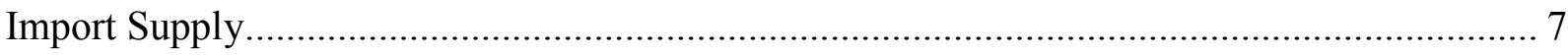

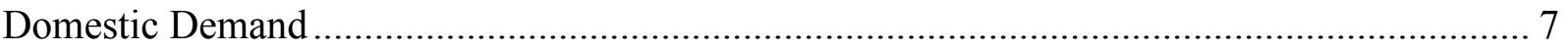

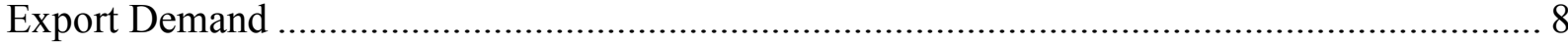

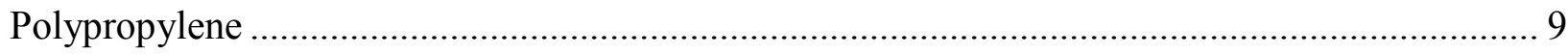

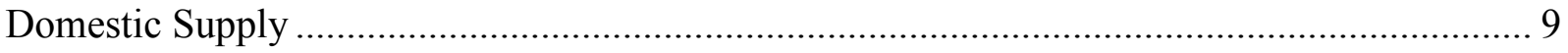

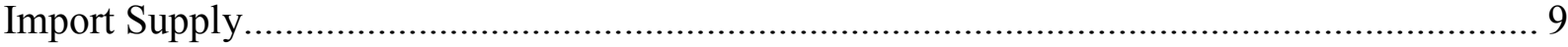

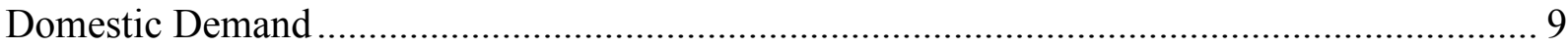

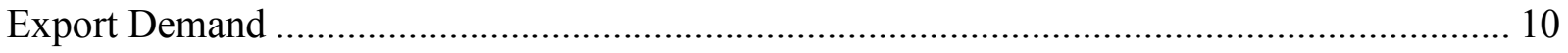

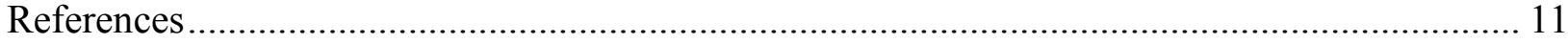




\section{Agent Methodology}

The structure of the agent-based model and firm behavior is illustrated using urea as an example. A urea manufacturing firm is created for each U.S. urea plant. Each seller agent is given a unit production cost based on nameplate capacity. The production cost assumes 2013 raw material prices, and raw material supply is unconstrained, so the production sub-agent (Figure 2) can produce a quantity in each time step up to the maximum capacity with no constraints. The production level for each time step is dictated by the strategist sub-agent based on the available space in product storage and the magnitude of orders received. If an order comes in but not enough material is in storage to fulfill the order, the order is denied and the production sub-agent is instructed to increase urea production if possible.

A buyer agent for urea fertilizer consumption is created for each county with estimated wholesale fertilizer distribution. The rate of urea consumption is estimated based on the methodology in the section below. For example, the Maricopa County, AZ urea buying agent seeks to purchase 15,000 MT of urea per year. The buyer sub-agent for Maricopa County demand goes to the urea Market to buy urea. When the material is delivered it is placed in storage, so the buyer sub-agent works to keep the warehouse stocked at a given level. The actual urea consumption occurs when urea is removed from storage and "consumed." Consumption is simulated by a production sub-agent that is similar to the seller's production sub-agent, although with no material produced.

The shipper is a separate agent which ships discrete quantities of urea from one seller to a buyer in the Market. The manufacturer's seller sub-agent ships a product by requesting the shipper to pick up and deliver the material to its destination. The shipper agent uses the transportation network to deliver urea so the cost of delivery is determined based on the transportation mode and distance. Maricopa County, for example, can receive shipments by truck or rail, but not by water. So Maricopa County can only buy urea from a seller that has access to the truck or rail urea Markets. Intermodal transport is included, so a shipment can originate on a waterway network and transfer to the truck or rail network for eventual delivery to Maricopa County. The Maricopa County buyer sub-agent attempts to place an order at a supplier that enables the lowest transportation cost (since urea sales at the point of production are uniform at the 2013 average urea price in the baseline scenario so all sellers sell urea at the same price). The lowest transportation cost between buyer and seller is based on distance and transport mode. If the order placed by Maricopa County is denied because the seller does not have enough material in storage, the Maricopa County buyer sub-agent continues to contact other sellers on the Market until a desirable sale can be made. Purchases of urea on the Market are subject to constraints such as minimum quantities (wholesale or retail quantities).

The buyer agent can inquire about sales prices and availability on the urea Market before placing an order so is continually able to search for the lowest price available. This behavior is important for the simulations where sales price is set entirely by the seller agents and not the 2013 market price (Section 4.1.1). As sellers change prices, exploring profit margin flexibility, 
each buyer evaluates the price it is willing to pay based on transportation mode, distance, and delivery timing. These individual agent actions of buying and selling discrete quantities of urea that occur for each time step are aggregated to provide the overall results presented in the manuscript that represent one year of market operation.

\section{Constraints and Degrees of Freedom}

Depending on the data used and subject matter expertise, markets can be constrained in terms of specific "blocked" trade relationships between particular countries, based on known trade sanctions, international treaty arrangements, or sovereign-state prohibitions of trade with other states. They can also be constrained by very high export or import tariffs, which can significantly increase the FOB-buyer price. Finally, markets can be constrained by only having particularly expensive or "slow" modes of transportation. All three affect the countries from which an individual commodity buyer will purchase.

From a related perspective, the degrees of freedom for buyers, producers, sellers, and transporters of commodities are generally:

- Buyers can buy from any seller that is in its market, i.e., its group of sellers that are "willing and able" to sell to that buyer. This means it is the same commodity, the seller does not have trade restrictions preventing the sale, the seller has the quantity (or portion thereof) that the buyer wants, and there is at least one mode of transportation common between them (rail, road, water).

- Sellers will sell to whomever asks for a purchase. Buyers have already "prequalified" the sale by determining that it is the right commodity, they can trade, and they share a mode of transportation.

- Shippers ship any commodity that has been requested on their network, and for which they have the capacity to ship the quantity. These shipments are generally over multimode (different ways to ship) and multi-modal (shipments can be transferred from rail to water, etc.) transportation networks, based on shortest-path algorithms and cost-per-mile-ton costs.

Simulation time for this model is 3-7 minutes depending on the degrees of freedom the analyst chooses to implement. 


\section{Urea}

The 2013 urea market is simulated by estimating domestic supply, import supply, domestic demand, export demand, and retail and wholesale prices.

\section{Domestic Supply}

Urea plant locations and capacities are reported by AmmoniaIndustry.com. ${ }^{1}$ Urea production for any plants with missing urea capacity data is estimated by allocating total U.S. 2013 production $^{2}$ weighted by the anhydrous ammonia capacity of the plant reported by AmmoniaIndustry.com or USGS 2013 Minerals Yearbook: Ammonia. ${ }^{3}$

The urea unit production cost for each plant was estimated based on the approximate cost of ammonia and then urea production. The ammonia unit cost was calculated using the plant's anhydrous ammonia capacity and the 2012 IHS Chemical Process Economics Program (PEP) Yearbook data for Ammonia from Natural Gas by Steam Reforming - M.W. Kellogg's Improved Process with an operating rate of $100 \%$. The unit production cost calculated from the 2012 PEP Yearbook is assumed to represent a 2013 production cost. The feedstock natural gas price used is a representative 2013 industrial natural gas price from the U.S. Energy Information Administration (EIA). ${ }^{4}$ The unit cost of producing ammonia for each plant was then used as the input ammonia cost for the urea production process. The urea unit production cost was calculated from the 2012 PEP Yearbook data for Urea, Agricultural Grade, by the Stamicarbon Process and is assumed to represent a 2013 production cost. For the urea process it was assumed that all existing plants have completely paid off all fixed assets, so the unit operating cost does not contain a fixed cost component. The calculated process costs for five plants (Agrium Borger, CF Industries Woodward, CF Industries Yazoo City, LSB Industries Cherokee, and LSB Industries Pryor) were higher than the approximated wholesale price of urea in 2013. The calculated process costs for these five plants were corrected to reflect the average profit margin of the other plants.

\section{Import Supply}

Quantities of urea imports from all countries to the United States were retrieved from the United Nations Comtrade database for commodity 310210 (urea including aqueous solution in

packs $>10 \mathrm{~kg}$ ). ${ }^{5}$ The trade value in U.S. dollars was divided by the trade quantity to provide an approximate unit price, which is used as the production cost for each import supply node (country). Country locations were approximated as the location of the largest ocean port, river port, or port city in the country. Countries with import quantities that were less than 100 metric tons (MT) during 2013 were removed from the model. The calculated unit cost for imports from Mexico and India are an order of magnitude higher than all other countries. A mass-weighted average unit cost for their global region was used to replace the reported unit cost for the two countries. 
To improve resolution of the urea industry in North America, total reported imports from Canada were allocated to each province using Canadian Business Patterns data instead of representing Canada as one import node. Approximate magnitude of urea imported from each province was calculated by weighting total Canadian urea imports by the number of chemical fertilizer manufacturing employees in each province (identified by 2012 NAICS 325313). ${ }^{6}$

\section{Domestic Demand}

The spatial distribution of urea fertilizer use in the U.S. was calculated using the number of wholesale farm supplies employees in each county to approximate the magnitude of demand. Employee data by county are from the 2013 U.S. Census County Business Pattern data for 2012 NAICS 424910 (farm supplies merchant wholesalers). The reported number of employees in each county was used to calculate the fraction of total U.S. urea fertilizer demand $(5,471,024$ MTA in 2013) $)^{2,7}$ assigned to each county. The county locations used the interpolated coordinate of the county's centroid from the USGS 2013 Gazetteer. ${ }^{8}$ Domestic consumption of urea for nonfertilizer use is not included.

\section{Export Demand}

Quantities of urea exports by trade partner country were retrieved from the United Nations Comtrade database for commodity 310210 (urea including aqueous solution in packs $>10 \mathrm{~kg}$ ). ${ }^{5}$ Country locations were approximated as the location of the largest ocean port, river port, or port city in the country.

To improve resolution of the urea industry in North America, total reported Canadian exports were allocated to each province using Canadian Business Patterns data instead of representing Canada as one export node. Approximate magnitude of urea exports to each province was calculated by weighting total urea exports to Canada by the total number of agricultural chemical and other farm supplies merchant wholesalers employees (2012 NAICS Canada 418390) in each province. ${ }^{9}$

\section{Prices}

Retail urea prices in the U.S. and Canada vary based on sales region because of differences in fertilizer taxes. The GABLES software places a lower bound on the price difference between demand node regions based on input data. The 2013 average urea price for each region in the U.S. and Canada was calculated using prices reported by Green Markets. ${ }^{10}$ Shipment volumes below 10 MT are considered retail, while shipments above 10 MT are considered wholesale. Each region is given historical retail and wholesale prices. 


\section{Propylene}

The 2013 propylene market is simulated by estimating domestic supply, import supply, domestic demand, and export demand.

\section{Domestic Supply}

Propylene in the U.S. is supplied from fractionation (concentrators/splitters), steam cracking, and propane dehydrogenation (PDH) plants. Refinery production is not included in this model. 2012 propylene plants and their propylene production capacity were reported by ICIS Chemical Business and are assumed to be representative of 2013 suppliers. ${ }^{11}$ ICIS does not report the type of propylene production facility, so steam crackers were identified using the Oil \& Gas Journal 2013 International Survey of Ethylene from Steam Crackers. ${ }^{12}$ Fractionation and PDH units were identified from company websites.

The unit production cost for the PetroLogistics Houston PDH plant (acquired by Flint Hills Resources in 2014) was estimated using the 2012 PEP Yearbook data for Propylene from Propane by OLEFLEX Dehydrogenation Process with a production capacity of 544,000 MT/yr. The unit production cost calculated from the 2012 PEP Yearbook is assumed to represent a 2013 production cost.

The unit production costs for the fractionation locations were estimated using the 2012 PEP Yearbook data for Propylene, Polymer Grade from Refinery Grade Propylene (66 wt \% $\left.\mathrm{C}_{3} \mathrm{H}_{6}\right)$ and is assumed to represent a 2013 production cost. There are six fractionation units at Mont Belvieu, with a total capacity of 95 thousand barrels per day (MBPD). ${ }^{13}$ It is assumed that all six units are the same capacity, so the economics were calculated for a $660,000 \mathrm{MT} / \mathrm{yr}$ unit. Baton Rouge Propylene Concentrator LLC's assets are assumed to be one $23 \mathrm{MBPD}$ unit. ${ }^{13}$ The assumed refinery grade propylene purchase cost is \$1,257/MT (average of 2013 Q2, Q3, and Q4 prices). ${ }^{14}$

The unit production cost for each steam cracker requires stoichiometric data for the amount of propylene produced per unit of ethylene. The propylene production capacity published by ICIS was divided by the Oil \& Gas Journal reported ethylene capacity ${ }^{12}$ (which utilizes a typical 2013 feedslate to calculate ethylene capacity) to determine the mass ratio of propylene to ethylene for typical operations during 2013. The unit cost of ethylene production was calculated using the 2012 PEP Yearbook data for Ethylene from Ethane-Propane by Conventional Cracking/Front-End Deethanization. The unit production cost calculated from the 2012 PEP Yearbook is assumed to represent a 2013 production cost. Using the stoichiometric ratio calculated for propylene production, the unit cost was converted to a mass propylene basis and corrected for sale of ethylene coproduct using an ethylene price of $\$ 1,168 / \mathrm{MT}$.

Three fractionators and two crackers (ExxonMobil Beaumont and Formosa Plastics Point Comfort) had production costs that are greater than the polymer grade propylene market price in 2013 (\$1471.14/MT), so their production cost was reduced to reflect the average profit margin from other similar plants. Unlike the urea suppliers, capital costs were included in the propylene 
unit production cost because many steam crackers in the United States have received investments in recent years to maximize runs of light feedstocks, ${ }^{15}$ Enterprise Products Partners' fractionators have been expanded within the last decade,${ }^{16}$ and the Houston PDH plant began operation in October $2010 .^{17}$

The Four Corners plant propylene production was modeled using ICI's leading concept methanol (LCM) two stage reforming step, followed by Lurgi's methanol-to-propylene technology.

\section{Import Supply}

Propylene was only imported from Canada in 2013. Propylene import data was retrieved from the United Nations Comtrade database for commodity 290122 (propene/propylene). The trade value in U.S. dollars was divided by the trade quantity to provide an approximate unit price, which was used as the production cost for Canadian imports. The location for Canadian imports was assumed to be Edmonton, Alberta.

\section{Domestic Demand}

Propylene is used primarily for the manufacture of polypropylene (PP), propylene oxide, acrylonitrile, cumene, acrylic acid, n-butanol, 2-ethyl hexanol (2-EH), and isopropanol. These eight products represented about $97 \%$ of domestic propylene demand in $2014 .{ }^{18}$ Propylene demand is estimated at plants where these eight products are produced domestically. To determine the location and capacity of each of these chemical plants that require propylene, the latest available ICIS U.S. Chemical Profile was used. The operating rate of each plant was assumed to be $90 \%$ unless more accurate 2013 operating rate data was found. The stoichiometric ratio of propylene required per mass product was from the 2012 IHS Chemical PEP Yearbook. This methodology provided an approximation of the magnitude of propylene demand required by each chemical plant based on product capacity, operating rate, and stoichiometry. The specific sources and assumptions for each propylene demand chemical plant are shown in Table S-1. 
Table S-1: $\quad$ Data sources and assumptions for propylene demand chemical plants.

\begin{tabular}{llll}
\hline Chemical & Plant Location Source & $\begin{array}{l}\text { Operating } \\
\text { Rate (\%) }\end{array}$ & Source \\
\hline Polypropylene & $\begin{array}{l}\text { US Chemical Profile: Polypropylene, ICIS } \\
\text { Chemical Business, July 2-15, 2012 }\end{array}$ & 79.23 & (a) \\
\hline Propylene oxide & $\begin{array}{l}\text { U.S. Chemical Profile: Propylene oxide, ICIS } \\
\text { Chemical Business, March 28, 2011 }\end{array}$ & 90 & Assumed \\
\hline Acrylonitrile & $\begin{array}{l}\text { U.S. Chemical Profile: Acrylonitrile, ICIS } \\
\text { Chemical Business, June 30 - July 6, 2014 }\end{array}$ & 75.47 & (b) \\
\hline Cumene & $\begin{array}{l}\text { U.S. Chemical Profile: Cumene, ICIS Chemical } \\
\text { Business, August 15, 2011 }\end{array}$ & 85.61 & (c) \\
\hline Acrylic acid & $\begin{array}{l}\text { U.S. Chemical Profile: Acrylic acid, ICIS } \\
\text { Chemical Business, February 18-24, 2013 }\end{array}$ & 90 & Assumed \\
\hline n-Butanol & $\begin{array}{l}\text { U.S. Chemical Profile: N-butanol, ICIS Chemical } \\
\text { Business, September 23-29, 2013 }\end{array}$ & Assumed \\
\hline 2-Ethyl hexanol & $\begin{array}{l}\text { U.S. Chemical Profile: 2-EH, ICIS Chemical } \\
\text { Business, January 7-13, 2013 }\end{array}$ & 90 & ICIS \\
\hline Isopropanol & $\begin{array}{l}\text { U.S. Chemical Profile: Isopropanol, ICIS } \\
\text { Chemical Business, April 14-20, 2014 }\end{array}$ & 90 & Assumed \\
\hline
\end{tabular}

a: Total North America PP production in 2013 was 16,427 million pounds. ${ }^{19}$ U.S. PP sales were $84 \%$ of the North America total in $2014 .{ }^{20}$ The same percentage is assumed to apply to U.S. production and be valid for 2013. Therefore, $84 \%$ of 16,427 million pounds gives the approximate U.S. PP production in 2013 , which compared to the nameplate capacity gives the apparent operating rate.

b: Total U.S. production of acrylonitrile from ICIS News ${ }^{21}$ was compared to the ICIS Chemical Business total reported nameplate capacity.

c: Total U.S. production of cumene in 2012 from ICIS News ${ }^{22}$ was scaled to a 2013 production level using the American Chemistry Council U.S. Chemical Production Regional Index, which indicated a $1.2 \%$ growth for 2013 as a whole. ${ }^{23}$ This total level of production was compared to the ICIS Chemical Business total reported nameplate capacity to calculate an approximate operating rate.

\section{Export Demand}

2013 propylene exports were retrieved from the United Nations Comtrade database for commodity 290122 (propene/propylene). Country locations were approximated as the location of the largest ocean port, river port, or port city in the country. 


\section{Polypropylene}

The 2013 polypropylene (PP) market is simulated by estimating domestic supply, import supply, domestic demand, and export demand.

\section{Domestic Supply}

Polypropylene plant names and capacities were retrieved from ICIS Chemical Business ${ }^{24}$ with specific plants locations retrieved from individual company websites. The unit production cost at each plant was calculated using the 2012 IHS Chemical PEP Yearbook data for Polypropylene via Basell's Multizone Circulating Reactor Process based on the ICIS reported nameplate capacity and a propylene raw material price of $\$ 1,471 / \mathrm{MT}$ (average polymer grade propylene price for $2013 \mathrm{Q} 2, \mathrm{Q} 3$, and Q4). ${ }^{14}$ The unit production cost calculated from the 2012 PEP Yearbook is assumed to represent a 2013 production cost. It was assumed that all plants have completely paid off all fixed assets, so the unit operating cost does not contain a fixed cost component. The calculated production costs were then scaled to give at most a $10 \%$ profit margin from the $2013 \mathrm{PP}$ price.

Polypropylene production in the Four Corners was modeled using the propylene process described in the Propylene section, followed by Basell's Multizone Circulating Reactor process for polymerization.

\section{Import Supply}

Polypropylene import data was retrieved from the United Nations Comtrade database for commodity 390210 (polypropylene in primary forms). The trade value in U.S. dollars was divided by the trade quantity to provide an approximate unit price, which was used as the production cost for each import node. The country category "Other Asia" was added to the imports from China. Country locations were approximated as the location of the largest ocean port, river port, or port city in the country. The location for Canadian imports was assumed to be Edmonton, AB.

The calculated unit costs for Nicaragua, New Zealand, Ireland, and Guatemala were an order of magnitude higher than all other countries. To correct the unit costs for these countries, a mass-weighted average unit cost for their global region was calculated and used to replace the reported number.

\section{Domestic Demand}

Total polypropylene sales and captive use in the U.S., Mexico, and Canada was 16,396 million pounds in 2013 (7,437,100 MT). ${ }^{19}$ U.S. PP sales were $84 \%$ of the North America total in $2014 .{ }^{20}$ This distribution of U.S. sales in the North America region is assumed to also be valid in 2013. Therefore, total PP sales in the U.S. in 2013 total 6,247,000 MT.

The spatial distribution of PP use was calculated using the number of plastics product manufacturing employees in each county to approximate the magnitude of demand. Employee 
data by county are from the 2013 U.S. Census County Business Pattern data for 2012 NAICS 3261 (plastics product manufacturing). The NAICS industries included in plastics processing are shown in Table S-2. The reported number of employees in each county was used to calculate the fraction of total U.S. PP demand assigned to each county. The county locations used the interpolated coordinate of the county's centroid from the USGS 2013 Gazetteer. ${ }^{8}$

Table S-2: NAICS industries included in plastics processing demand calculation.

\begin{tabular}{ll}
\hline Industry Description & $\begin{array}{l}\mathbf{2 0 1 2} \\
\text { NAICS } \\
\text { Code }\end{array}$ \\
\hline Plastic bag and pouch manufacturing & 326111 \\
\hline Plastic film and sheet manufacturing & 326114 \\
\hline Unlaminated plastic profile shape manufacturing & 326121 \\
\hline Plastic pipe and pipe fitting manufacturing & 326122 \\
\hline Laminated plastic plate, sheet (except packaging), and shape manufacturing & 326130 \\
\hline Plastic plumbing fixture manufacturing & 326191 \\
\hline Motor vehicle plastic parts manufacturing & 326193 \\
\hline Plastic window and door manufacturing & 326196 \\
\hline All other plastic product manufacturing & 326198 \\
\hline
\end{tabular}

\section{Export Demand}

U.S. 2013 polypropylene exports were retrieved from the United Nations Comtrade database for commodity 390210 (polypropylene in primary forms). Country locations were approximated as the location of the largest ocean port, river port, or port city in the country. To improve resolution of the PP industry in North America, total reported Canadian exports were split up to each province using Canadian Business Patterns data instead of representing Canada as one import node. As with domestic PP demand, approximate magnitude of PP exported to each province was calculated by weighting total Canadian PP exports by the number of plastics processing industry employees (2012 NAICS 3261) in each province. ${ }^{25}$ 


\section{References}

1. AmmoniaIndustry.com, Ammonia Plants in North America, March 2015.

2. U.S. Geological Survey (USGS), 2013 Minerals Yearbook: Nitrogen, August 2015, http:// minerals.usgs.gov/minerals/pubs/commodity/nitrogen/myb1-2013-nitro.pdf (accessed September 16, 2015) Table 3.

3. U.S. Geological Survey (USGS), 2013 Minerals Yearbook: Nitrogen, August 2015, http:// minerals.usgs.gov/minerals/pubs/commodity/nitrogen/myb1-2013-nitro.pdf (accessed September 16, 2015) Table 4.

4. U.S. Energy Information Administration (EIA), Natural Gas Prices, Industrial Price, http:// www.eia.gov/dnav/ng/ng_pri_sum_dcu_nus_a.htm (accessed September 16, 2015).

5. United Nations Comtrade Database, http://comtrade.un.org/data/ (accessed February 25, 2016).

6. Statistics Canada, Table 551-0005 - Canadian business patterns, location counts, employment size and North American Industry Classification System (NAICS), national industries, by Canada and provinces, December 2013, semi-annual, CANSIM. NAICS 325313 - Chemical fertilizer (except potash) manufacturing, http://www5.statcan.gc.ca/ cansim/pick-choisir?lang=eng\&p2=33\&id=5510005 (accessed September 14, 2015).

7. International Fertilizer Industry Association (IFA), Data, http://ifadata.fertilizer.org/ ucSearch.aspx, accessed September 14, 2015.

8. United States Census Bureau, 2013 U.S. Gazetteer Files, https:/www.census.gov/geo/mapsdata/data/gazetteer2013.html (accessed February 25, 2016).

9. Statistics Canada, Table 551-0005 - Canadian business patterns, location counts, employment size and North American Industry Classification System (NAICS), national industries, by Canada and provinces, December 2013, semi-annual, CANSIM. NAICS 418390 - Agricultural chemical and other farm supplies merchant wholesalers, http:// www5.statcan.gc.ca/cansim/pick-choisir?lang=eng\&p2=33\&id=5510005 (accessed September 14, 2015).

10. Green Markets, http://www.fertilizerpricing.com/, accessed September 14, 2015.

11. ICIS Chemical Business, Propylene: U.S. Chemical Profile, 19-25 November 2012, page 35.

12. Koottungal, L. International Survey of Ethylene from Steam Crackers - 2013, Oil \& Gas Journal, 2013, 111 (7), http://www.ogj.com/content/dam/ogj/print-articles/ 
Volume\%20111/july-1/International-Survey-of-Ethylene-From-Stream-Crackers.pdf (accessed September 15, 2015).

13. Enterprise Products, Propylene Fractionation \& Services, http://www.enterprise products.com/operations/propyleneFract.shtm (accessed September 15, 2015).

14. Lippe, D. 2013 ethylene output rises; growth to continue in early 2014, Oil \& Gas Journal, 2014, 112 (3), http://www.ogj.com/articles/print/volume-112/issue-3/processing/2013ethylene-output-rises-growth-to-continue-in-early-2014.html (accessed September 16, 2015).

15. RBN Energy, What's Crackin' with Steam Crackers, Drill Down Report, September 2014.

16. Enterprise Announces Construction of New Propylene Splitter and Expansion of Propylene Gathering Pipelines, Houston Chronicle, March 23, 2006, http://www.chron.com/news/ article/BW-Enterprise-Announces-Construction-of-New-1906915.php (accessed February 25, 2016).

17. Flint Hills Resources, http://www.petrologistics.com/operations.html (accessed February 25, 2016).

18. Plotkin, J. The propylene gap: how can it be filled? American Chemical Society Cutting-Edge Chemistry, September 15, 2015, http://www.acs.org/content/acs/en/pressroom/cuttingedge-chemistry/the-propylene-gap-how-can-it-be-filled.html (accessed December 16, 2015).

19. American Chemistry Council, U.S. Resin Production \& Sales 2014 vs. 2013, March 2015, http://www.americanchemistry.com/Jobs/EconomicStatistics/Plastics-Statistics/ Production-and-Sales-Data-by-Resin.pdf (accessed September 11, 2015).

20. American Chemistry Council, Year in Review for Resins - 2014, "North American Resins Industry Expands in 2014 Despite Weakness in Key Export Markets", https:// www.americanchemistry.com/2009-year-in-review (accessed September 11, 2015).

21. Dang, T. US Q4 2013 ACN output up 1.3\% year on year - AFPM, ICIS News, February 6, 2014, http://www.icis.com/resources/news/2014/02/06/9751006/us-q4-2013-acn-outputup-1-3-year-on-year-afpm/ (accessed September 11, 2015).

22. Dietrich, J. US 2012 cumene production increase $0.2 \%$ year on year, ICIS News, January 31 , 2013, http://www.icis.com/resources/news/2013/01/31/9636780/us-2012-cumeneproduction-increases-0-2-year-on-year/ (accessed September 11, 2015). 
23. American Chemistry Council, U.S. Chemical Production Expanded in December; 2013 Ends on a High Note, January 24, 2014, http://www.americanchemistry.com/Media/ PressReleasesTranscripts/ACC-news-releases/US-Chemical-Production-Expanded-inDecember-2013-Ends-on-a-High-Note.html (accessed September 21, 2015).

24. ICIS Chemical Business, US Chemical Profile: Polypropylene, July 2-15, 2012.

25. Statistics Canada, Table 551-0005 - Canadian business patterns, location counts, employment size and North American Industry Classification System (NAICS), national industries, by Canada and provinces, December 2013, semi-annual, CANSIM. NAICS 326111, 326114, 326121, 326122, 326130, 326191, 326193, 326196, 326198. 